\title{
Polish Americans in the History of Bilingual Lexicography: The State of the Art
}

\author{
Mirosława Podhajecka, Institute of English, University of Opole, \\ Poland (mpodhajecka@uni.opole.pl)
}

\begin{abstract}
This paper measures dictionaries made by Polish Americans against the development of the Polish-English and English-Polish lexicographic tradition. Of twenty nine monoscopal and biscopal glossaries and dictionaries published between 1788 and 1947, four may be treated as milestones: Erazm Rykaczewski's (1849-1851), Władysław Kierst and Oskar Callier's (1895), Władysław Kierst's (1926-1928), and Jan Stanisławski's (1929). Unsurprisingly, they came to be widely republished in English-speaking countries, primarily the United States of America, for the sake of Polishspeaking immigrants. One might therefore wonder whether there was any pressing need for new dictionaries. There must have been, assuming that supply follows demand, because as many as eight Polish-English and English-Polish dictionaries were compiled by Polish Americans and published by the mid-twentieth century. The scant attention accorded this topic suggests a chronological approach to these dictionaries is in order, firstly, to blow the dust from the tomes; secondly, to establish their filial relationships; and, lastly, to evaluate their significance for the bilingual dictionary market.
\end{abstract}

Keywords: HISTORY, BILINGUAL LEXICOGRAPHY, BILINGUAL DICTIONARY, POLISH AMERICANS, SOURCE LANGUAGE (SL), TARGET LANGUAGE (TL), EQUIVALENT, LEXICOGRAPHER, TRADITION

Opsomming: Poolse Amerikaners in die geskiedenis van tweetalige leksikografie: Die jongste stand. In hierdie artikel word woordeboeke wat saamgestel is deur Poolse Amerikaners gemeet aan die ontwikkeling van die Pools-Engelse en Engels-Poolse leksikografiese tradisie. Van die nege en twintig eenrigting- en tweerigtingglossariums en -woordeboeke wat tussen 1788 en 1947 gepubliseer is, kan vier as mylpale beskou word: Dié van Erazm Rykaczewski (1849-1851), Władysław Kierst en Oskar Callier (1895), Władysław Kierst (19261928), en Jan Stanisławski (1929). Dit is nie verbasend nie dat hulle wyd in Engelssprekende lande, veral in die Verenigde State van Amerika, ter wille van die Poolssprekende immigrante herpubliseer is. Daar kan dus gewonder word of daar enige dringende behoefte aan nuwe woordeboeke was. Indien daar aangeneem word dat aanbod op aanvraag volg, moes daar wel so 'n behoefte gewees het, aangesien agt Pools-Engelse en Engels-Poolse woordeboeke teen die middel van die twintigste eeu deur Poolse Amerikaners saamgestel is. Die min aandag wat al aan hierdie onderwerp geskenk is, dui daarop dat 'n chronologiese benadering tot hierdie woordeboeke geskik is, eerstens om die woordeboeke te herontdek, tweedens om hul onderlinge verwantskappe te bepaal, en laastens om hul waarde vir die tweetalige woordeboekmark te evalueer. 
Sleutelwoorde: GESKIEDENIS, TWEETALIGE LEKSIKOGRAFIE, TWEETALIGE WOORDEBOEK, POOLSE AMERIKANERS, BRONTAAL (BT), DOELTAAL (DT), EKWIVALENT, LEKSIKOGRAAF, TRADISIE

\section{Introduction}

This paper concentrates on the history of Polish-English and English-Polish bilingual lexicography up until the mid-twentieth century, with particular attention paid to dictionaries compiled by Polish Americans. The dictionarymaking tradition has received very little treatment thus far. Suffice it to say that Grzegorczyk's Index lexicorum Poloniae (1967), a bibliography of dictionaries that is now critically out of date, ${ }^{1}$ is one of the few sources of information in this respect.

This study, which is a continuation of the research presented in Podhajecka (2016a), ${ }^{2}$ is based on the premise that the bilingual dictionary, despite its ubiquity in the Western world, has been greatly underestimated. ${ }^{3}$ It was, however, born in response to a real need to understand texts in foreign languages, and it remains a practical tool rather than a book that languishes on the shelf, as Adamska-Sałaciak (2014: 1) so simply and disarmingly put it. By bridging gaps between two languages and cultures, moreover, the bilingual dictionary allows for successful cross-linguistic communication and, for this reason alone, its status in the realm of lexicography should be seen as truly unique.

\section{The historical background}

The history of Polish-English and English-Polish lexicography, in which Polish was either the source language (SL) or the target language (TL), begins with a short glossary in a book of grammar published in 1788. It was compiled by Julian Antonowicz, a Basilian monk and teacher. The glossary included a total of 800 Polish headwords thematically arranged and paired with their English equivalents. It was not, however, devised by Antonowicz. The model was copied from a French-English glossary in Boyer's The Compleat French-Master ... (1729), a popular handbook of French aimed at native speakers of English. As Antonowicz spoke French fluently, he translated French headwords into Polish, leaving the English equivalents intact. This is exactly how the glossary came into being, indicating what had become a standard trend in practical lexicography long before the eighteenth century: the use of others' lexical data.

Judging by the number of reprints and new editions, ${ }^{4}$ four dictionaries that came out between 1849 and 1929 may be treated as milestones in the history of Polish-English and English-Polish lexicography. Their potential was soon noticed by publishers in English-speaking countries, primarily the United States of America, and they took steps to republish them for the convenience of the Polish diaspora. ${ }^{5}$ The dictionaries are briefly described below. 
[Erazm Rykaczewski]. 1849-1851. A Complete Dictionary English and Polish and Polish and English Compiled from the Dictionaries of Johnson, Webster, Walker, Fleming and Tibbins, etc., from the Polish Lexicon of Linde and the Polish German Dictionary by Mrongovius. This volume English and Polish ... (Vol. 1). Dokładny słownik polskoangielski i angielsko-polski, czerpany z najlepszych źródeł krajowych i obcych; a mianowicie ze słowników polskich: Lindego, Mrongoviusa i Ropelewskiego; $z$ angielskich: Johnson, Webster, Walker, Fleming-Tibbins i innych. Ten tom polsko-angielski ... (Vol. 2). Berlin: B. Behr.

This was the first comprehensive dictionary of Polish and English, the EnglishPolish part including over 26,000 headwords and the Polish-English part nearly 30,000, compiled by Erazm Rykaczewski (1803-1873), a graduate of Vilnius University, a historian, editor and teacher, and an insurgent in the November Uprising forced to seek refuge abroad. Rykaczewski was a novice in the field of practical lexicography, but he was a polyglot and an experienced dictionary user. Unsurprisingly, to compile a dictionary for languages that had not been paired before, ${ }^{6}$ he turned to reference works for other language pairs, primarily English-French and English-German, rendering the TL lexicographic information taken from them into Polish. Although Rykaczewski used a handful of dictionaries, J.G. Flügel's Complete Dictionary of the English and German ... (1830) was his main source of data. He is claimed to have compiled both volumes during a ten-year stay in Scotland (Lewandowski 1992: 473). From 1870 onwards, the dictionary appeared under the authorship of Alexander Chodźko (1804-1891); the change in copyright remains a controversy which, despite Chodźko's note appended to the 1870 edition, has not been fully resolved (see Podhajecka 2016a: 100-103). The last edition known to exist came out in Chicago around $1950 .{ }^{7}$

Kierst, W. and O. Callier. 1985. English-Polish and Polish-English Dictionary / Stownik jezzyka polskiego i angielskiego. Vols. 1-2. Leipzig: Otto Holtzes Nachfolger.

The dictionary by Władysław Kierst (1868-1945) and Oskar Callier (1846-1929) was a small pocket edition, a mere quarter the size of Rykaczewski's, offering close to 29,000 headwords, i.e. half the scope of Rykaczewski's. It was, in all likelihood, compiled single-handedly by Kierst. ${ }^{8}$ Arranging words in the little space available required the use of specific devices and niching, i.e. the clustering of related words alphabetically in an entry, turned out to be an effective solution. In the long run, it helped the dictionary successfully to challenge Rykaczewski's monopoly, the more so because it was aimed at the mass market. It was republished until 1961.

Kierst, W. (Ed.). 1926-1928. Trzaska, Evert and Michalski A Dictionary EnglishPolish and Polish-English. Część pierwsza angielsko-polska (Vol. 1). Second Part: PolishEnglish (Vol. 2). Warsaw: Trzaska, Evert \& Michalski. 
In the 1920s, Trzaska, Evert \& Michalski (TEiM), the well-known Warsaw publishers, issued another dictionary by Władysław Kierst, who had in the meantime made his name as the translator of Edgar Rice Burroughs's Tarzan stories (e.g. Burroughs 1922). With 32,000 headwords in two handy volumes, the dictionary was only a little more comprehensive than its predecessor. ${ }^{9}$ Nevertheless, Kierst approached his task diligently, working methodically to update the entire text of the dictionary with monolingual works, including Webster's Collegiate Dictionary (1919) for English and Stownik ilustrowany języka polskiego (1916) for Polish. The last edition appeared in 1984.

Stanisławski, J. 1929. An English-Polish and Polish-English Dictionary / Stownik angielsko-polski i polsko-angielski. Warsaw: Skład Główny Księgarnia Wysyłkowa G. Dorn.

This biscopal dictionary was a large pocket edition with nearly 30,000 headwords in both parts. ${ }^{10}$ Comparative analyses revealed that it was not compiled from scratch. The extent to which Stanisławski (1893-1973) borrowed from Kierst's TEiM dictionary has been estimated at in excess of $80 \%$ (Podhajecka 2016a: 358). One should not underestimate Stanisławski's expertise, however, as he was not a mere imitator, but a genuine innovator. More exactly, he improved three aspects of lexicographic description: firstly, he included phonetic transcription closer to the International Phonetic Alphabet, the European standard at that time, than any other system applied thus far; secondly, he added new headwords and natural-sounding equivalents; ${ }^{11}$ and, thirdly, he used brief explanatory glosses to distinguish between senses. The dictionary was in use until 1993, and most probably beyond this date, when it was last published by Tormont, a Canadian publisher.

\section{Polish American dictionaries}

The above dictionaries were widely republished in the United States, so one might wonder whether there was any need to bring onto the market brand-new endeavors. Apparently there was, at least judging by the list of lexicographic works compiled by Polish Americans. ${ }^{12}$ Suffice it to say that demand for bilingual dictionaries appears when there is a real or anticipated need for interlingual communication and, hence, works facilitating it. ${ }^{13}$ As Micklethwait (2005: 133) remarks, "A nation if immigrants, especially one with a cultural inferiority complex and an insatiable appetite for self-improvement, provides a ready market for dictionaries". ${ }^{14}$ The dictionaries will be presented and briefly evaluated below. If there were any subsequent reprints or editions, this will be signified by means of a vertical arrow. Translations of Polish headwords or equivalents in square brackets are my own and so are translations of quotations accompanied by my initials. 
S.Z. and W.B. 1899. Stownik kieszonkowy polsko-angielski i angielsko-polski. Chicago: Nakład Spółki Wydawnictwa Polskiego.

Stownik kieszonkowy polsko-angielski i angielsko-polski was the first English-Polish and Polish-English dictionary aimed specifically at Polish immigrants in America, particularly those residing in Chicago, who were soon to become the city's dominant ethnic group (Hargraves 2011: 50). It was compiled by two authors whose identities were concealed behind the initials S.Z. and W.B. Tracing the authorship of anonymous works is fraught with difficulty and this lexicographic work is a case in point. The Polish Publishing Company built on Chicago's Polish Catholic circles is the only clue to the identities of the compilers.

The first of the authors was Szczęsny Zahajkiewicz (1861-1917), who used the initials S.Z. as his cryptonym (Maciejewski and Szweykowski 1982: 253). He was a recognized teacher, editor, poet and playwright, but his lexicographic activity was a new string to his bow. The identity of his co-author is more problematic because there were at least three people in Chicago's Polonia with the initials W.B. with whom Zahajkiewicz collaborated: Wincenty Barzyński (1847-1899), a veteran priest at the St. Stanislaus Kostka Church; Władysław Barwig (1858-?), a parish secretary and the head of a drama group there; and Wiktor Bardoński (1852-1928), the first Polish pharmacist to practise in the state of Illinois.

Still another possible collaborator was Władysław Bełza (1847-1913), one of the most active literati in nineteenth-century Lvov, in today's Ukraine (Czartoryski-Sziler n.d.). In fact, Bełza never visited America, but he knew Zahajkiewicz from his home city and corresponded with members of Chicago's Polonia, such as Paweł Sobolewski. ${ }^{15}$ Having been regarded as a chronicler of Polishness who "provided many proofs of his merits and unblemished integrity" [M.P.] (Kąsinowski 1913: 83), Bełza was a likely collaborator in the compilation of a dictionary aimed at Polish immigrants. For the time being, however, the involvement of any of the above-mentioned figures cannot be established reliably, so the authorship of the dictionary remains a riddle. ${ }^{16}$

S.Z. and W.B.'s dictionary was a simple abridgement of Rykaczewski's endeavor. The compilers took approximately $30 \%$ from the wordlist of the parent dictionary in each part, thus omitting a great many headwords. The entry structure consisted of their copying the equivalents, but disregarding most of the dictionary text (e.g. cross-references, grammatical information, SL contextual uses and their TL translations). Sense division was also significantly limited, as is shown below.

\begin{tabular}{|l|l|}
\hline \multicolumn{1}{|c|}{ S.Z. and W.B. } & \multicolumn{1}{c|}{ Rykaczewski } \\
\hline $\begin{array}{l}\text { Czas, u, s. m. time; 2) } \\
\text { weather; 3) (gram.), } \\
\text { tense. }\end{array}$ & $\begin{array}{l}\text { CZAS, U, s. m. time, 2) weather; (gram.), tense. Trawić czas na nauce, to } \\
\text { spend one's time in study. Tracić czas, to lose or waste one's time. } \\
\text { Powrócić w sam czas, to come back just in time or in the very nick of } \\
\text { time. Wolny czas, leisure. Teraz jest wtaśnie czas po temu, this is a favour- } \\
\text { able opportunity. Jeszcze nie czas figom, the time of figs is not yet. Za }\end{array}$ \\
\hline
\end{tabular}




\begin{tabular}{|l|l|}
\hline czasów Abrahama, in the time of Abraham. Za owych czasów, in those \\
times, in those days. Za dawnych czasów, in olden times, in times of old, \\
in times of yore. Od niepamiętnych czasów, in times out of mind. W \\
swoim czasie, in proper time and place. Wszystko dobre w swoim czasie, \\
all is in good time. Ciężkie czasy, troublesome, difficult, hard times. \\
Piękny lub brzydki czas, it is fine or fair, it is fine or bad weather. Od \\
czasu do czasu, from time to time, now and then. Tymczasem, meantime, \\
meanwhile. Wówczas lub podówczas, at that time, then ...
\end{tabular}

Table 1: A sample entry in S.Z. and W.B.'s and Rykaczewski's dictionaries

The cuts allowed S.Z. and W.B. to keep their own dictionary compact and concise; the Polish-English part included more than 18,000 entries over approximately 400 pages of pocket format and the English-Polish part more than 18,000 entries over 500 pages. The headwords were printed in the same type as the rest of the entry, at least in volume one, which suggests that user-friendliness was not yet an issue.

Paryski, A.A. 1899. Wielki ilustrowany angielsko-polski i polsko-angielski stownik, zawierajacy wszystkie wyrazy, zwroty $i$ przysłowia, używane w mowie $i$ literaturze angielskiej i polskiej, oraz nazwy techniczne i geograficzne, imiona własne, wykazy skróceń, znaków, symbolów i. t.d., z podaniem wymowy, sylabilizacyi i form gramatycznych. Część 1: Stownik angielsko-polski [Instalments 1-?]. Toledo, OH.

Paryski, A.A. 1899. Kieszonkowy stownik polsko-angielski. Toledo, OH: Antoni A. Paryski.

Paryski, A.A. 1900. Kieszonkowy słownik angielsko-polski, zawierajacy przeszło 40.000 wyrazów używanych $w$ mowie i literaturze angielskiej, z podaniem dokładnej wymowy każdego wyrazu, opracowany na podstawie stowników szkolnych Webster'a, Worchester'a $i$ Standard. Toledo, OH: Nakład, druk i własność A. A. Paryski.

Paryski, A.A. 1900. Stownik polsko-angielski i angielsko-polski oraz nauka wymowy angielskiej. 7th edition. Toledo, OH: Nakład, druk i własność A. A. Paryskiego.

The turn of the twentieth century witnessed robust lexicographic activity in America. This was, in large measure, due to Antoni A. Paryski (1865-1935), another Polish-American entrepreneur to undertake the compilation of bilingual dictionaries. Born in Poland to a peasant family, he must have had a good deal of stamina to pursue a career in America, where he worked hard to acquire English and to learn typesetting, printing, and then journalism to make a living. Several years after arriving in the United States, he set up a highly successful enterprise called the Paryski Publishing Company.

The scale of Paryski's involvement in the American publishing market is astonishing. As well as newspapers, primarily Ameryka-Echo, he issued close to eight million books, which earned him the reputation of "the Polish Hearst" (Jaroszyńska-Kirchmann 2015: 2). Majewski (2003: 41) argues that "in conjunction with newspaper publishing, book production could be very cheap, and very 
profitable", which suggests that Paryski steered into relatively safe waters. Thousands of the books were apparently dictionaries compiled by himself and, to give users an alternative, by Kierst and Callier. In any case, both were advertised regularly on the pages of Ameryka-Echo and sold by Paryski's salesmen criss-crossing the United States. ${ }^{17}$

Paryski was the author of the four volumes listed above, of which the first, Wielki ilustrowany angielsko-polski i polsko-angielski słownik ... (1899), was hailed as a reference work of unprecedented quality. It was to be an exhaustive dictionary with illustrations and an array of specialist terms, perhaps modeled on encyclopedic works such as Ogilvie's The Imperial Dictionary ... (1859-1860). It is unknown what brought the innovative project to a halt. According to Chojnacki (n.d.), there were only a few issues published in 1899. It is to be regretted that no single copy of the dictionary appears to have survived to date.

That the pocket versions offered the same lexical material is confirmed by the number of pages: the English-Polish part comprised 299 pages and the PolishEnglish part 155 pages. ${ }^{18}$ It is interesting that, even though the volumes were parts of one dictionary, they were priced differently: one monoscopal dictionary was sold at $\$ 1$, and the other at $\$ 1.5$. This may be indicative of Paryski's marketing skill. To compile the dictionary, he borrowed from a range of lexicographic works. His sources included Rykaczewski's (under Chodźko's name) A Complete Dictionary English and Polish ... (1890), Kierst and Callier's English-Polish and PolishEnglish Dictionary (1895), Whitney's The Century Dictionary ... (1895), and Webster's A Primary School Dictionary of the English language ... (1871).

It is unclear whether it was Webster's school dictionary or a description of English phonics regarded as a reading instruction, such as Practical Phonics ... (1881), ${ }^{19}$ that prompted Paryski's ingenious idea of combining spelling with pronunciation (see also Emans 1968, Barry 2008). Figure 1 provides an example of this.

\begin{tabular}{|c|c|}
\hline 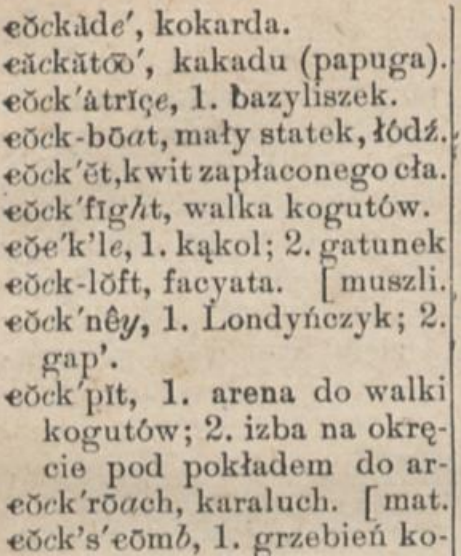 & 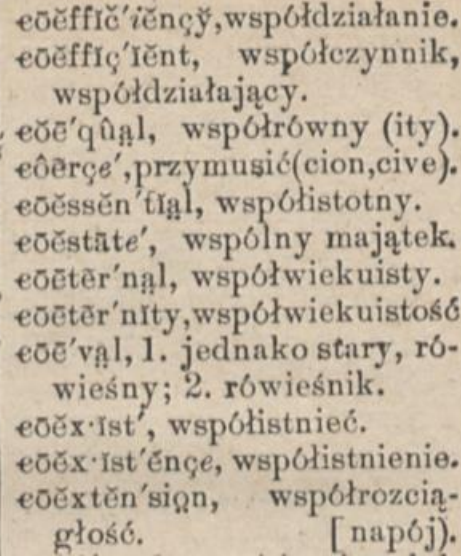 \\
\hline
\end{tabular}

Figure 1: A sample of Paryski's Stownik polsko-angielski i angielsko-polski ... (1900) 
There is no way of knowing what American students consulting Webster's school dictionaries thought of the notation system consisting of a range of diacritical marks and awkward characters, ${ }^{20}$ but they were evidently drilled on it in the classroom. By contrast, the system must have been extremely confusing for Polish learners of English. Be that as it may, one of the reasons why users consult bilingual dictionaries is for information on spelling. To my knowledge, there is no research data on dictionary use in the past, but it may be safely assumed that bilingual dictionaries in immigrant communities were purchased mainly to be used at home.

Paryski's dictionary, including over 24,000 entries in both parts, was largely a labor of love. The English and Polish wordlists were far from comprehensive, grammatical information was missing, contextual uses were infrequent, phraseology was scarce, and TL equivalents were not always chosen with semantic wisdom, e.g. cartel 'dostawa żywności' [food supplier] (> 'kartel'), chess 'warcaby' [checkers] (> 'szachy'), fiance 'narzeczona' [fiancée] (> 'narzeczony'), and swum 'płyną' [(he/it) swam] (> 'past participle of swim'). On the other hand, Paryski added new headwords, new senses, and new equivalents (e.g. szynk 'saloon; inn') in order to modify the dictionary in accordance with the changing times and, in particular, the American context. For example, he was the first lexicographer to pair dandruff with its modern counterpart 'łupież' (cf. Rykaczewski's 'papry na głowie' [dirt on the head]) and whisky with 'wódka' (cf. Rykaczewski's 'gorzałka' [booze]).

The E-P part was more extensive than the P-E part. One might assume that Paryski experienced some sort of "alphabet fatigue" (Osselton 2007: 81-91) in compiling it. ${ }^{21}$ To put it differently, this part is unsophisticated content-wise, as Paryski usually paired each Polish headword with only one English equivalent. In doing so, he also borrowed from Rykaczewski's dictionary much more frequently and less critically than he did in the E-P part. All this suggests that he may have been a brilliant entrepreneur with a flair for business, but he was no first-class lexicographer.

Since S. Z. and W. B.'s and Antoni Paryski's dictionaries relied on Rykaczewski's work, their volumes might have been similar. Still, while S.Z. and W.B. took all their lexical material, truncating it severely, from the parent dictionary with no serious modifications, Paryski at least attempted to contribute to the dictionary in his own way.

Słowniczek Polsko-Angielski z wymowq fonetycznq. [pre-1905]. Chicago: Smulski Publishing Company.

This tiny booklet, a collection of basic words, was published anonymously by the Chicago-based Smulski Publishing Company. It is a great rarity today inasmuch as the Polish Museum of America in Chicago is the only acknowledged institution that has a copy of it. The publication date of the Stowniczek [Little dictionary] is missing from the title page, but there are reasons for claiming that it appeared prior to 1905. 
The envisaged readership was unspecified, but the dictionary was probably compiled for the benefit of those Polish immigrants who knew little or no English, but who could at least read and write. After all, thousands of newcomers to America at that time were illiterate. The Stowniczek included around 2,500 headwords in three columns (see Figure 2), the majority of which were borrowed from Rykaczewski's dictionary and some from Kierst and Callier's. To the entry structure was added simple phonetic transcription expressed solely in Polish graphemes. The size and low price must have been the booklet's main strengths.

\begin{tabular}{lll}
\multicolumn{1}{c}{ Tekst polski. } & Tekst angielski. & \multicolumn{1}{c}{ Wymawia się. } \\
stary, & old, & old. \\
statek, & vessel, ship, & wessel, szyp. \\
stanąc, & to stop, to pause, tu stap, tu pauz. \\
stawiac, & to set, to place, & tu set, tu plejs. \\
stekac, & to groan, & tu gron. \\
stelmach, & wheel-wright, & hull-rajt. \\
ster. & rudder, helm, & rodder, nelm. \\
stluczony, & broken to pleces, & broken tu pises. \\
stol, & table, & tejbel. \\
stolarz, & joiner, & dżojner. \\
stolek, & stool, & stul. \\
stolica, & capltal, & kiapytel. \\
stopa, & foot, & fut. \\
stoplen, & step, & step.
\end{tabular}

Figure 2: A sample of the Stowniczek (pre-1905)

An analysis of the content suggests that it is likely to have been compiled by Modest Maryański, a brief biographical sketch of whom is given below, albeit there is no concrete evidence for such an accreditation.

Maryański, M. 1906. Jedyny w swoim rodzaju przewodnik polsko-angielski i stownik polsko-angielski dla wychodźców polskich i przybyszów do Stanów Zjednoczonych Ameryki Pótnocnej i Kanady, ułatwić mający stawianie kroków pierwszych w kraju obcym $i$ nauke języka angielskiego, $z$ podaniem wymowy $i$ brzmienia każdego wyrazu angielskiego według metody fonetycznej, z dotączeniem niektórych uwag, rad i wskazówek. Chicago: Własnym nakładem.

$\downarrow$

1907. Warsaw: Gebethner and Wolff.

The volume titled "a unique Polish-English guide-book" for "Polish immigrants and newcomers to the United States of North America and Canada" [M.P.] was compiled by Modest Maryański (1854-1914), a Polish mining engineer. Although the date on the title page is 1905 , the book was not published until 1906.22 
The story has it that, in 1887, Maryański went to the United States (his original destination was Australia) in search of "bread", as he himself put it (Paszkowski 2008: 292). This is somewhat difficult to believe since he was previously the founder of a company exploiting the Truskawiec mine in Galicia (Maryański 1882: 3), in the Austrian-Hungarian Empire, and, two years later, its managing director (Chłapowski 1884: 173). ${ }^{23}$ Since Maryański's biography is very patchy, we may only rely on hypotheses. One of them assumes that he invested his money in a risky business or unsuccessful speculations, bringing his family (wife and son) to the brink of poverty. ${ }^{24}$ In America, with no English, he worked as a builder and miner, experiencing various ups and downs on the way. His plight was so difficult at one point that he was considering suicide. It was only working as a mining expert at a gold mine in Colorado that eventually made him a wealthy man; as stated by Paszkowski (1987: 304), the Consolidated Kosciusko Mine was employing twenty to seventy five miners and "the returns were satisfactory", at least at first. Even though Maryański's fortunes soon changed to see him plying his trade as a newspaper editor, he was admittedly one of the best-known Polish-American self-made men of the day.

\begin{tabular}{|c|c|c|}
\hline $\begin{array}{l}\text { stary, } \\
\text { starzec, } \\
\text { statek, } \\
\text { staw, } \\
\text { stanąć, } \\
\text { stawiać, } \\
\text { stękać, } \\
\text { stękanie, } \\
\text { stelmach, } \\
\text { step, } \\
\text { stempy, } \\
\text { ster, }\end{array}$ & $\begin{array}{l}\text { old, } \\
\text { an old man, } \\
\text { vessel, ship, } \\
\text { joint, pond, } \\
\text { to stop, to pause, } \\
\text { to set, to place, } \\
\text { to groan, } \\
\text { groaning, } \\
\text { wheel-wright, } \\
\text { prairie, } \\
\text { stamping mill, } \\
\text { rudder, helm, }\end{array}$ & $\begin{array}{l}\text { ōld. } \\
\text { en öld men. } \\
\text { wessel, szyp. } \\
\text { dżojnt, pand. } \\
\text { tu stap, tu pāz. } \\
\text { tu set, tu plejs. } \\
\text { tu grōn. } \\
\text { grōning. } \\
\text { huīl-rajt. } \\
\text { preri. } \\
\text { stamping myll. } \\
\text { rodder, helm, }\end{array}$ \\
\hline
\end{tabular}

Figure 3: A sample of Maryański's dictionary part (1906)

The book was divided into three parts: "Przewodnik Polsko-Angielski" [A PolishEnglish Guide-book], "Słownik Polsko-Angielski z wymowa fonetyczną" [A Polish-English Dictionary with Phonetic Transcription] and "Część trzecia" [Part Three]. The first and the last part included information which, in Maryański's view, was essential to Polish immigrants. As for the dictionary part (see Figure 3), each page was divided into three vertical columns: one for the English headwords, one for the Polish equivalents, and one for the phonetic transcriptions. The similarity between Maryański's wordlist and the Stowniczek is not incidental: among the 4,000 Polish headwords that found their way into 
Maryański's dictionary, 2,500 were taken directly from the Stowniczek. The transcription was also aimed at an inexperienced dictionary user, and the only difference here was a macron over vowel sounds (e.g. â) to signify length.

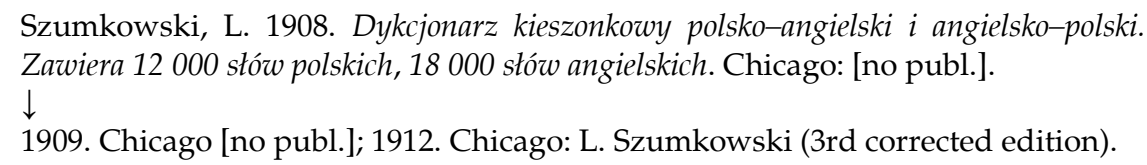

This pocket dictionary was another reference work by a Polish American targeted at the huge, and steadily growing, Polish community in Chicago. The dictionary, the costs of whose publication were covered by Leonard S. Szumkowski (1885-1954), went into three editions. As an advertisement in Stowo Polskie (1912) informed prospective buyers, ${ }^{25}$ the main attributes of the dictionary were its exhaustive wordlists, its low price (75 cents), its hard-wearing leather cover, and its pocket format. The claims regarding its coverage at least were no exaggeration: the Polish-English part included over 11,000 headwords and the English-Polish part over 14,500, even though the figures fall short of Szumkowski's own estimates. ${ }^{26}$ The text, as may be seen in Figure 4, was dense in order to save space.

There is no doubt that Szumkowski made an effort to modernize and Americanize the lexical material, but his dictionary was hardly an update. It was compiled solely on the basis of Rykaczewski's and Paryski's works. In addition to the core vocabulary, it included peripheral items useless to the target readership, such as historicisms (e.g. chaperon 'kaptur' and scholiast 'tłumacz') and dialecticisms (e.g. bożyć 'to swear' and przynuka 'compulsion'). Although most TL equivalents were satisfactory, some were clearly wrong (e.g. grzywna 'reward' [fine, penalty] and weird 'czarownik' [wizard]), and the quality of the phonetic transcription was poor.

\begin{tabular}{|c|c|}
\hline $\begin{array}{l}\text { housemaid, -mejd, służąca } \\
\text { housewife,-wajf, gospodyni } \\
\text { housing, -ing, czaprak } \\
\text { hovel, how'el, chata } \\
\text { hover, -er, unosić się } \\
\text { how, hau, jak } \\
\text { however, hauew'er, jednak } \\
\text { howl, hauł, wyć } \\
\text { hub, hob, piasta } \\
\text { huckster, -ster, szachraj } \\
\text { huddle, hod'ł, pogmatwać } \\
\text { hue, hiu, barwa } \\
\text { huff, hof, chelpliwośc } \\
\text { huffish, -yś, fukliwy } \\
\text { hug, hog, uścisnienie } \\
\text { huge, hiudź, wielki }\end{array}$ & $\begin{array}{l}\text { hurdle, bor'd\}, płotek } \\
\text { hurl, horł, zgiełk } \\
\text { hurrah, hura', hura! } \\
\text { hurricane, hor'ykiejn, bu- } \\
\text { rza } \\
\text { hurry, -y, spieszyé } \\
\text { hurt, hort, urazić } \\
\text { husband, hoz'band, mąż } \\
\text { husband, gospodarować } \\
\text { husbandman, rolnik } \\
\text { husbandry, rolnictwo } \\
\text { hush, hos, cyt! } \\
\text { husk, hosk, hupina } \\
\text { husking, -ing, huszczący } \\
\text { husky, -y, lupiniasty } \\
\text { hussar', huzar }\end{array}$ \\
\hline
\end{tabular}

Figure 4: A sample of Szumkowski's English-Polish part (1908) 
Szumkowski arrived in the United States as a boy and attended American schools, so he must have been fully bilingual. He was a doctor of medicine specializing as a surgeon, but his professional career was not limited to his medical practice. Above all else, his technical inventions allowed him, in 1918, to establish the Ursus Motor Company. In his capacity as president of the corporation, he left for Europe in 1920 with the idea of helping the newly-re-established Poland. Having allegedly received "the best possible concessions from the Polish government" [M.P.] (Lokański 1920: 345), he purchased premises in Warsaw in order to begin the production of trucks and tractors. He came back to the United States in May 1921, but there is no information on his later exploits.

Jesień, W. 1925. Stownik angielsko-polski zawierajacy 4000 najpospoliciej używanych słów. Warsaw: Michał Arct.

Wacław Jesień's Stownik angielsko-polski ... (1925) is a large pocket edition with a collection of American English vocabulary paired with Polish equivalents. It was aimed at immigrants or, more precisely, prospective immigrants aspiring to the status of naturalized Americans. As the title page informed prospective buyers, Wacław Jesień (1886-1937) was "a former specialist in foreign languages at the American Bureau of Education" [M.P.]. Even though little is known about his life, he was indeed employed by the Bureau in the 1910s. The English-Polish dictionary might thus be seen as a continuation of his career in education.

The project is interesting in that the list of 4,000 English words ${ }^{27}$ was compiled by Alfred E. Rejall, professor of psychology and specialist in adult education for the State of New York. It became the basis for the New York State Regents' literacy test for new Americans, assessing their reading comprehension (Stinchfield-Hawk 1928: 162). As Rejall did not determine the senses that new Americans should be acquainted with, the task of transforming the wordlist into a fully-fledged bilingual dictionary was assumed by Jesień. Closer analysis suggests that he consulted both monolingual and bilingual sources for this purpose, but Stownik angielsko-polski ... (1925) also reflects his own ideas regarding the appearance of such a "learner-oriented dictionary". ${ }^{28}$ This includes, among other things, the choice of TL equivalents, a proportion of which were translated literally from English into Polish. One of them is surprise '... niespodziewane najście lub atak, zdziwienie, przedmiot wywołujący zdziwienie lub oszołomienie' [an unexpected intrusion or attack, astonishment, an object causing astonishment or bewilderment]. ${ }^{29}$ 


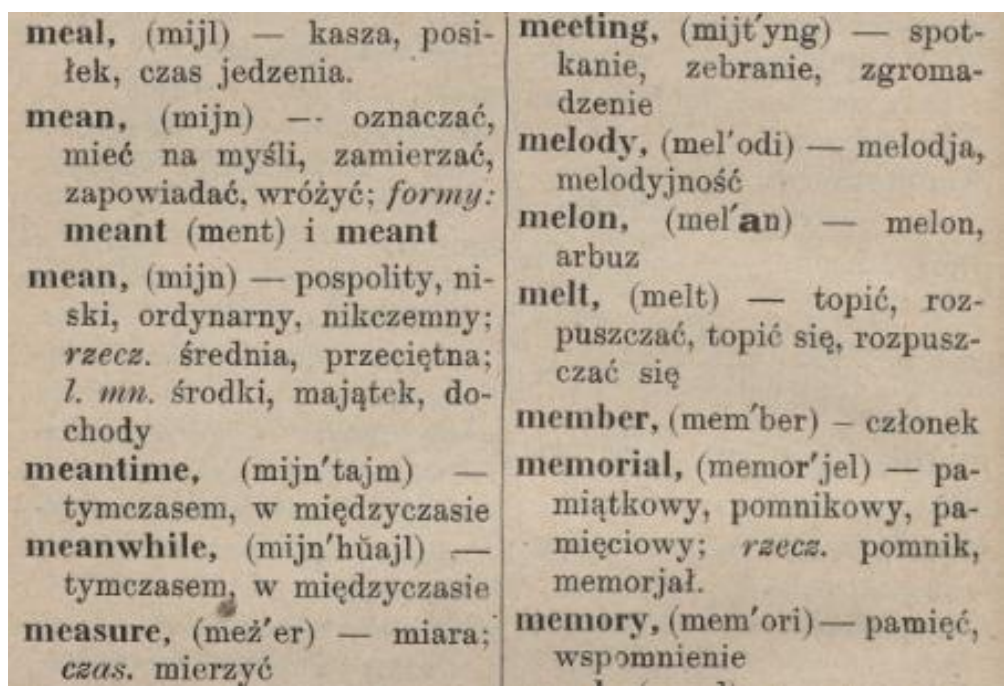

Figure 5: A sample of Jesień's Słownik angielsko-polski ... (1925)

On the other hand, Jesien introduced phonetic transcription indicating, fairly effectively, American pronunciation and a significant number of Americanisms (e.g. Decoration Day 'dzień wieńczenia grobów (święto amerykańskie)', drugstore 'apteka', eagle 'orzel, moneta złota 10-dolarowa', Fourth of July 'Czwarty Lipiec (Święto niepodległości w Ameryce)', gas/gasoline 'gaz, gazolina, benzyna motorowa ...' and highway 'droga, gościniec'). Taking everything into account, the dictionary should have been welcomed by future emigrants, but, for unknown reasons, it never ran into a second edition.

Wilde, T.M. 1928. Smulski's Dictionary. An English-Polish and Polish-English Pocket Dictionary / Stownik Smulskiego angielsko-polski i polsko-angielski. Stownik kieszonkowy. Chicago: Polish-American Publishing Co. 1944. Chicago: Polish-American Book Co. $\downarrow$

Smulski, J.F. and T.M. Wilde. 1945. Stownik angielsko-polski polsko-angielski z wymowa. Poznań: Wydawnictwo Polskie R. Wegnera (Oddział w Norymberdze). ${ }^{30}$

Smulski's Dictionary (1928) was compiled by T.M. Wilde (1858-1943), a sergeant major in the United States Army, a commander in the Kosciuszko Guard, editor of Kuryer Polski, and a bank examiner in Wisconsin (Podhajecka 2016a: 319-321). Let me cite the preface to the dictionary in its entirety:

Realizing an urgent need of a modern English-Polish dictionary, Mr. John F. Smulski gave the initiative to this work, and lent it his unstinted support and co- 
operation. More than two thousand modern words, not found in any existing English-Polish and Polish-English dictionary, have been included in the pocket edition herewith presented. Owing to the limited space, rare, obsolete, and purely technical words have of necessity been omitted. The dictionary comprises twenty thousand English, and sixteen thousand Polish words, with their proper equivalents. Phonetic pronunciation of each English word is indicated. Polish pronunciation is described and explained. Lessons in conversation for use of beginners will be found in the appendix.

The preparation and printing of the dictionary was financed by John F. Smulski (1867-1928), an American lawyer, millionaire banker, businessman, politician of Polish origin, and a philanthropist (see, e.g. Kantowicz 1975: 64). ${ }^{31}$ The volume was to include as many as 36,000 headwords in both parts, of which more than 2,000 were to be brand new.

Since it was a small pocket edition, the TL equivalents were the main component of the entry structure and other kinds of lexicographic information, such as phonetic transcription and labels, were kept to an absolute minimum (see Figure 6). As my findings reveal, Smulski's Dictionary was based on Kierst and Callier's and the TEiM dictionaries. Given the influence of the former, it should come as no surprise that the Polish equivalents (e.g. aborigines 'tuziemcy') are sometimes old-fashioned, indicating that Wilde had not succeeded in updating the whole dictionary as consistently as he had planned. Most of the 2,000 new headwords, such as dziurawka 'hollow brick', etażerka 'what-not' and łechtaczka 'clitoris', were borrowed from the so-called Stownik warszawski [Warsaw Dictionary], the largest monolingual dictionary of Polish. They were apparently paired with their English counterparts on the basis of Wilde's interlingual competence.

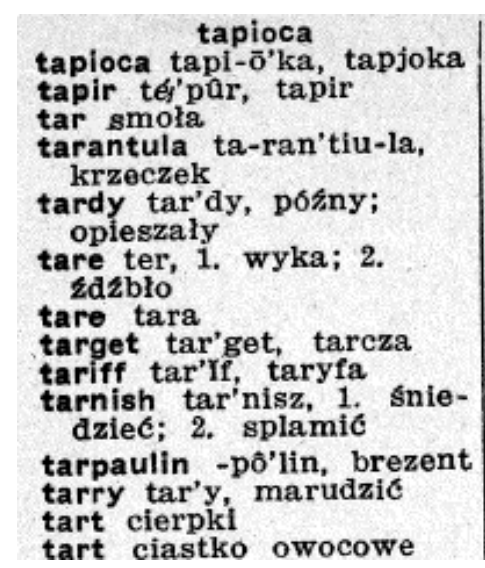

Figure 6: A sample of Wilde's Smulski's Dictionary (1928)

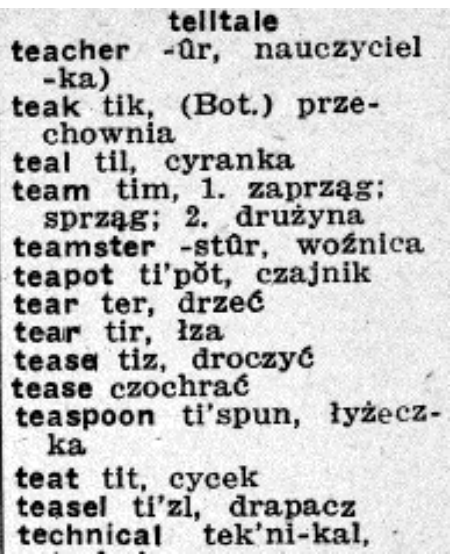


Despite drawing on several existing sources, Smulski's Dictionary showed a great deal of lexicographic creativity, providing new equivalents (e.g. Wilde's tarantula 'krzeczek' / Kierst's 'tarantula (pajak)') and equivalents for new senses (e.g. Wilde's angina 'dusznica' [angina pectoris] / Kierst's 'angina, zapalenie gardła' [tonsillitis]). In this way, it was not only a derivative but also an innovative English-Polish / Polish-English dictionary, even though some equivalents were imperfect (e.g. szalenie 'furiously' (> 'madly, exceedingly'), włosień 'long hair from horse's tail' (> 'a helminth in mammals') and wścibski 'meddler' (> 'meddlesome')).

Lilien, E.L. 1944. Lilien's Dictionary. Part 1: English-Polish / Ernesta Liliena słownik. Cz. 1: Angielsko-polski. Buffalo: Drukiem Dziennika dla Wszystkich [Instalment 1]; 1944-1945. Buffalo: Wydawnictwa Słownika Liliena / Stevens Point: Wydawnictwa Słownika Liliena [Instalments 2-8]; 1947-1951. Stevens Point: Wydawnictwa Słownika Liliena [Instalments 9-19].

This dictionary, compiled by Ernest Lilien (1872-1952), is the only one examined in this paper that is left unfinished. Lilien's death in 1952 thwarted his extraordinary plan to make an entirely new English-Polish and Polish-English dictionary modelled on unabridged American dictionaries, primarily so-called Webster's Second (1934), the largest dictionary of English. ${ }^{32}$ Such a project was an enormous undertaking, particularly as all the editorial duties were assumed by Lilien himself single-handedly (letter to Mizwa of 8 June 1944). The coverage of the English-Polish part, the first and only to have been compiled, was estimated at 115,000 headwords, but only approximately half of it, i.e. 19 out of the 40 planned instalments, appeared in print.

Ernest Lilien was born to a rich Jewish family in Lvov. Before emigrating to America in 1916, he was a businessman. ${ }^{33}$ In the United States, by contrast, he was known primarily as a journalist in Stevens Point. Prior to that, he had edited several Polish-language newspapers in Buffalo, Detroit, Toledo, and Chicago, as stated by the author of his obituary in The Milwankee Journal (1952). ${ }^{34}$ His scope of interests was, however, far wider. ${ }^{35}$

Lilien worked on his dictionary for the last twenty or so years of his life. The publication, as we learn from the preface, was supported by St. Peter's Foundation in Stevens Point thanks to the Reverend Julius Chylinski. ${ }^{36}$ Additional backing came from the Kosciuszko Foundation, an organization of American Polonia, which subscribed to "a substantial portion of the printed installments as they appeared" (Mizwa 1961: v). ${ }^{37}$ The Embassy of the Polish People's Republic in Washington also showed its appreciation for Lilien's effort by subscribing to 200 copies of the dictionary, of which 194 were to be distributed among libraries, universities, and cultural institutions in Poland. ${ }^{38}$ 

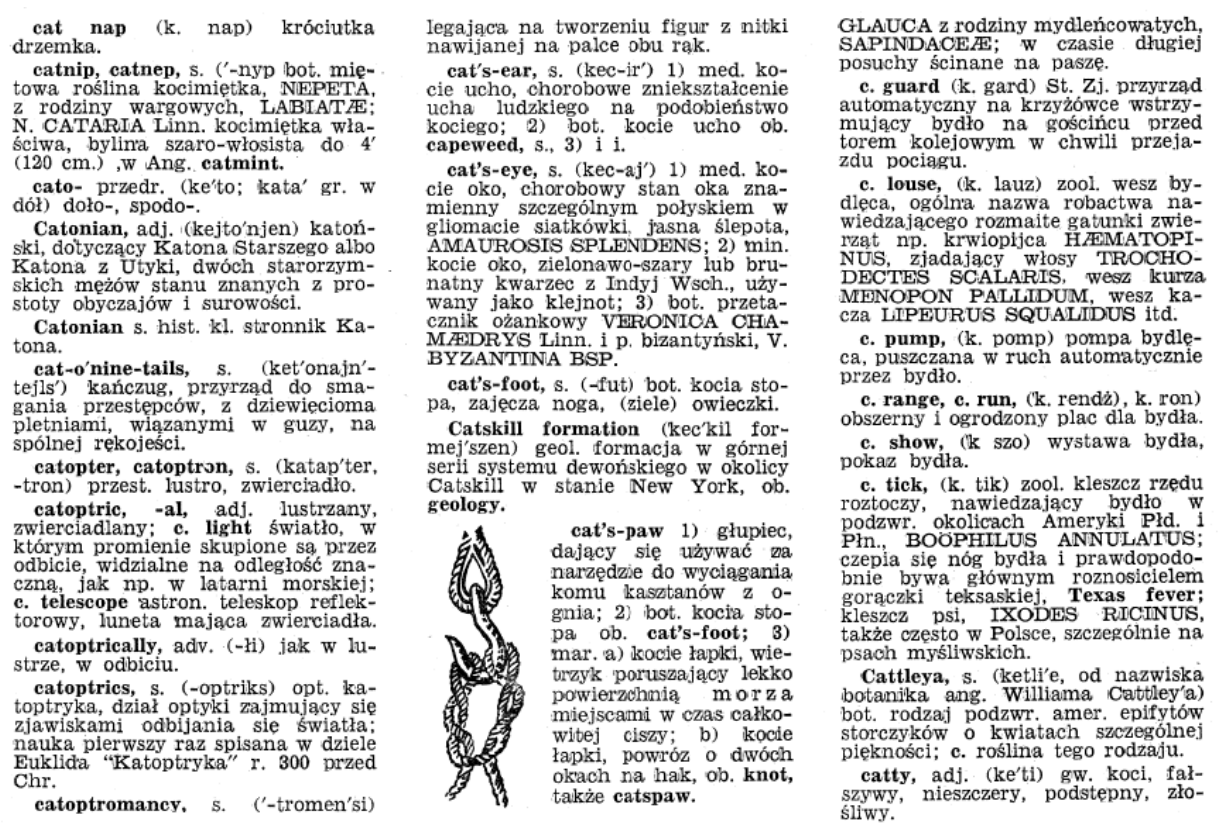

Figure 7: A sample of Lilien's Dictionary (instalment 8, 1945)

Lilien's motivations are explained in a two-page preface appended to the first instalment. Briefly, the compilation was triggered by an urgent need for a modern exhaustive English-Polish and Polish-English dictionary for both everyday and specialist uses. Two reference works typical of the American lexicographic tradition, Webster's Second (1934) ${ }^{39}$ and Funk and Wagnalls dictionary (1893), were said to be Lilien's direct models. ${ }^{40}$ A simplified phonetic transcription was employed, which became the subject of harsh criticism in a lexicographic work with such lofty aspirations (e.g. Scherer 1946), and the "most exact translations" and "brief definitions" [M.P.] were regarded as a necessity. It is worthy of note that Lilien not only used American English dictionaries, but he also turned to a number of bilingual and multilingual ventures, including Stownik morski [Maritime Dictionary], Matankin's Stownik wojskowy [Military Dictionary], and Wlekliński et al.'s Stownik techniczny [Technical Dictionary] (Lilien 1944: 3).

With hindsight, any assessment of this dictionary would have to take cognizance of Lilien's intention to describe over 100,000 English words, a great many of which were borrowed from Webster's Second and, occasionally, Funk and Wagnalls. Some of the words, including those originating in other world Englishes, were admittedly of little use for Polish Americans. Examples include billy tea '(Australia) herbata parzona w kociołku billy' [(Australia) tea brewed in a billy pot], cachude 'med. pastylka, używana w Indiach jako odtrutka i jako 
środek przeciw zaburzeniom żołądkowym i spazmom' [med. a pill used in India as an antidote to gastric problems and convulsions], and gora, gorah, goura 'instrument muzyczny Hotentotów i Buszmanów w Afr.' [a musical instrument used by Hottentots and Bushmen in Africa ${ }^{41}$. Other superfluous elements are narrow specialist terms, for which there were no Polish equivalents available (e.g. frog-eye 'patol. rośl. nazwa rozmaitych chorób znamiennych pierścieniami dokoła schorzałego miejsca ...' [pathol. veget. A name of various diseases forming characteristic rings around the infected spot ...]). The TL equivalents were, moreover, not always fitting, particularly from the point of view of translators, since Lilien frequently employed descriptive rather than single-word equivalents (e.g. gangster 'St. Zj. członek szajki złodziei, rabusiów, włamywaczy, rzezimieszków, fałszerzy, szantażystów itp ...' [U.S. a member of a gang of thieves, robbers, burglars, cutthroats, forgers, blackmailers etc.]). Nevertheless, as Mizwa (1961: v) rightly put it, "the author deserves honorable mention and commendation ... for being the first not only to sense the need of an extensive English-Polish and Polish-English dictionary but also to attempt to do something about it".

The gigantic bilingual material that Lilien collected could not go unnoticed. Indeed, there is some evidence that it was used in the compilation of the English-Polish part of the Kościuszko Foundation Dictionary (1959), a renowned lexicographic work compiled in Poland by Kazimierz Bulas, and revised in the United States in collaboration with Francis J. Whitfield and Lawrence L. Thomas, both of them affiliated with the Department of Slavic Languages and Literatures of the California University at Berkeley. Still, neither Bulas nor his American collaborators ever admitted this fact openly.

\section{Conclusions}

To summarize, the purpose of this paper was to shed some light on PolishEnglish and English-Polish dictionaries compiled by Polish Americans. Eight such dictionaries, of varying size and targeted at different readership, appeared on the American market between 1899 (S.Z. and W.B.; Antoni A. Paryski) and 1951 (Ernest Lilien). One of them, Wacław Jesień's Stownik angielsko-polski zawierajacy 4000 najpospoliciej używanych słów (1925), was published in Poland. It is hoped that this historical survey has some important merits as neither the dictionary-makers' biographies (except for Paryski's and Zahajkiewicz's) nor even their names appear in the otherwise comprehensive Polish American Encyclopedia (2011) edited by Pula et al.

The attractiveness of a dictionary to the target market is reflected by the number of editions to which it runs. Seen from this perspective, the dictionaries compiled by Polish Americans enjoyed little commercial success. Only four of them went through more than one edition: Maryański's guide-book was republished in Poland by Gebethner \& Wolff; Szumkowski published two fur- 
ther editions, of which the third is claimed to have been corrected; and Smulski's Dictionary had another Chicago edition of 1944, although it was also reprinted, presumably without copyright, in 1945 in Nuremberg by Wydawnictwo Polskie R. Wegnera. Paryski's pocket dictionary alone appeared in new versions; there were at least seven of them, but many more supposedly left the printing presses of the Paryski Publishing Company. It is worth emphasizing that Paryski had the printing infrastructure at his disposal, which he used to his advantage despite the fact that his dictionary was of a low quality. Given his "intelligence, determination, and energy" (Jaroszyńska-Kirchmann 2015: 204), it remains a moot point why he never made an effort to revise and improve it.

The authors described here were people from different walks of life, with different aspirations and different career paths, but none of them was a professional lexicographer. This may explain why their dictionaries - with the single exception of Lilien's Dictionary - were unambitious. There is every indication that they turned to practical lexicography to meet the exigencies of the "hyphenated" Polish-American market (see, e.g., Erdmans 2013: 225), cashing in on their knowledge of English which surpassed their fellow countrymen's. In spite of their limited experience in practical lexicography, they tailored their dictionaries, in one way or another, to target users' envisaged needs.

The history of lexicography is indicative of what may be called knowledge development. In a nutshell, establishing TL equivalents for SL headwords requires a network of lexical knowledge that is by no means restricted to a single compiler's cross-linguistic and cross-cultural competence. Polish Americans attempted to modernize and Americanize the network for the sake of Polish immigrants and, as might be expected, some did it more skilfully than others. The limitations of space require that this paper offer merely a sketch, but the history of bilingual lexicography resulting from my research contains fascinating stories about the compilers and the dictionaries they made.

One might ask what remains a desideratum in the field. There is always room for further research. Firstly, many biographical details are still unknown. Evidently the names of Paryski, Maryański, Szumkowski, Wilde, and Lilien may ring a bell for Polish-Americans, but their biographies are patchy and incomplete. Secondly, a few reference works have not been found, Paryski's illustrated dictionary being a case in point. Thirdly, information on how the dictionaries were used would make for a highly informative addition. Lastly, next to nothing is known about the post-war history of Polish-English and English-Polish lexicography, which is another challenge facing a historian of bilingual lexicography.

\section{Endnotes}

1. There are a few other bibliographies of dictionaries, including Collison's (1955), Lewański's (1959) and Wojan's (2013), but they are also far from complete. 
2. Over the last two years after the publication of the book, a number of additional details enriching the overall picture came to light. They have been diligently collected and shown in this article.

3. According to Hausmann (qtd. in Hartmann 2007: 209), the history of bilingual lexicography has not received much attention. The third volume of An International Encyclopedia of Lexicography edited by Hausmann et al. (1991) might suggest otherwise, as it includes a number of chapters dedicated to bilingual dictionaries for different languages pairs. It should be noted, however, that this refers primarily to the world's major languages, such as English, German, French, Italian, Chinese, and Arabic.

4. This distinction requires a word of comment. A new edition is usually seen as different from the original one (cf. Hartmann and James 2001: 47). As my research shows, however, it was not the case with bilingual dictionaries of the past because subsequent reprints were often publicized as "new editions", even though they underwent no revision. This also concerns dictionaries issued by a range of publishers, of which Franciszek Bauer-Czarnomski's PolishEnglish and English-Polish dictionaries may be a case in point (Podhajecka 2016a: 254).

5. The first wave of Polish political immigration in the nineteenth century was followed by a flood of economic migrants desperate to find social and financial stability for themselves and their families. Most publishers of the Polish-English and English-Polish dictionaries, i.e. Władysław Dyniewicz, Władysław Smulski, the Polish American Publishing Company (Dyniewicz and Smulski, from 1929 Helen and John J. Chrzanowski), the Polish American Book Company (Helen Chrzanowski) and A. A. Paryski, were of Polish descent. This might indicate that providing the Polish community with bilingual dictionaries was some kind of patriotic duty, but it was clearly expected to yield a profit. In the following years, it was not only ethnic publishers (e.g. David McKay) who came to realize that the bilingual dictionary business had the potential to be quite lucrative.

6. Rykaczewski's work had only been preceded by Krystyn Lach-Szyrma's monoscopal English-Polish dictionary (1828).

7. The catalogue of the Wisconsin-Madison Libraries suggests that the copy of the dictionary in the Libraries' possession might have been published between 1950 and 1959, whereas the metadata of the University of California Berkeley Libraries indicates that their copy appeared in 1954. I contacted both libraries with an inquiry, but it seems that the dates are approximate. The only way to determine them is to search methodically through the Polish-language newspapers published in Chicago between 1945 and 1960, which remains a daunting task.

8. In 1891, Kierst was a student at Warsaw University when he was arrested by the Russian police and sentenced to two and a half years in prison and a three-year-exile to Russia. Intriguingly, he must have compiled the dictionary during these years. For a former political prisoner to attract a publisher, however, would have been absolutely impossible, which prompted Kierst to turn to Oskar Callier, a secondary school teacher with some experience in practical lexicography.

9. It is worthy of mention that, between 1895 and 1926, Kierst made an attempt to compile another dictionary. Entitled Dokładny stownik angielsko-polski $i$ polsko-angielski $w$ dwóch częściach z wymowa wyrazów angielskich wedtug najnowszych źródet opracowany ... (1915-16), it was put out by Warsaw's Ksiegarnia Mazowiecka, but the publication was discontinued.

10. The same dictionary was later published by J. Lorenz, a Moravian publisher, who, in 1929, 
had commissioned Stanisławski to compile a large pocket dictionary embracing 45 printed sheets.

11. It is important to mention that Stanisławski was educated in England from an early age. He graduated from St. Michael's College in Hitchin, Herefordshire, in 1910 and was practically a native speaker of English.

12. This article is dedicated to the dictionary-making activity undertaken by, and aimed at, an immigrant community in the United States. Since Poles constituted one of many ethnic groups there, it would be worthwhile studying the topic from a comparative perspective, as one of the reviewers rightly suggests. This, however, would exceed the scope of this article, opening a broad research area with new challenges.

13. This also concerns thematic dictionaries. After World War II, for example, thousands of Polish soldiers and civilians remained in the United Kingdom, where they had to find ways to make a living. A number of bilingual thematic dictionaries appeared at that time, including Angielskopolski stownik spawalniczy ... (1946) by Moszoro, Stownik ślusarza angielsko-polski (1946) and Stownik betoniarza i zbrojarza polsko-angielski $i$ angielsko-polski (1947), to help them acquire specialist English vocabulary (see also Łukasik 2017).

14. Here, Micklethwait is referring to monolingual dictionaries, but bilingual ones were equally, if not more, indispensable.

15. In 1840, Sobolewski was himself engaged in compiling an English-Polish dictionary. He never saw it to fruition, however, having been discouraged by Count Adam Jerzy Czartoryski, whom he had approached for advice and help (Podhajecka 2016b: 330). Sobolewski's manuscript, extant in the alphabet range B-E, is found in the holdings of the Polish Library in Paris.

16. Despite many efforts undertaken by American Polonia to save its ancestors from oblivion, very little is known of most immigrants, particularly those whose names rarely appeared in the ethnic press.

17. Paryski was supposedly the author of a practical manual for his salesmen, Katechizm dla agenta oświatowego Wydawnictwa Ameryki-Echa, whom he called "educational agents" as their task consisted in the "dissemination of learning" [M.P.] (19--: 9). This "catechism" is organized on a question and answer basis, providing the agents with information on how, and why, to carry out their work. For example, in Section 6: The relationship between the agents and the Publishing Company, we read: "4. What is the next step in the agent's business career? Permitting accomplished agents, as shareholders, to benefit from the Company's profits. 5. Are these good promotion prospects? Extremely good, as the Company, developing thanks to the agents' fair and conscientious work, will soon have a turnover in millions [of dollars]" [M.P.] (19--: 17).

18. Only two copies of Paryski's pocket dictionary are available today: one in the Library of the Ossoliński National Foundation in Wrocław, and the other in the Sterling Memorial Library of Yale University in New Haven, Connecticut.

19. Practical Phonics, modelled on "the orthoepy of Webster's Dictionary", was published in America by Esmond de Graff, an established teacher and educator.

20. The system was not originally Webster's, as Micklethwait (2005: 134) shows. Indeed, the Royal Standard English Dictionary (1788) by William Perry may well be treated as a parent dictionary in this respect. 
21. The use of "alphabet fatigue", a feature of large dictionary projects (Coleman 2008: 68), in relation to small bilingual dictionaries may seem bizarre, but there is no better term. It is clear that other dictionary-makers were also determined to finish their works as quickly as possible. Paryski must have been exhausted after the compilation of the English-Polish part, which led him, firstly, to reduce the number of headwords (9,587 as opposed to 14,527 in the English-Polish volume) and, secondly, to make a rigid selection of equivalents in the PolishEnglish part.

22. The guide-book was entered at the Office of the Register of Copyrights in Washington, D.C., in 1905, but was published in 1906. This is confirmed by Maryański himself; on the back cover of his book, he explains that the print was delayed for reasons beyond his control.

23. Franciszek Chłapowski, who would later become professor of medicine at Poznań University and chair of the Poznań Association of the Friends of Sciences, is a reliable source of information.

24. This may obviously be a pure coincidence, but, in 1895 , the famous Polish writer and seaman Joseph Conrad "seems to have invested almost all of his money in South African goldmines" and lost it soon afterwards (Hampson 2012: 125). Dealings in gold shares would have been quite relevant, as Maryański managed gold mines in the United States, where he risked "his hard won fortune" (Paszkowski 1987: 304), and in Australia, where he once again decided to risk both his capital and good reputation (see Paszkowski 1987: 305-309).

25. The advertisement is available from the following website: http://www.fultonhistory.com/ Process $\% 20$ small/Newspapers/Newspapers\%20\%20Out\%20of\%20NY/Utica\%20NY\%20Slowo \%20Polskie\%20(The\%20Polish\%20Word)/Utica\%20NY\%20Slowo\%20Polskie\%20(The\%20 Polish\%20Word)\%201913.pdf/Utica\%20NY\%20Slowo\%20Polskie\%20The\%20Polish\%20Word $\% 20 \% 201913 \% 20(400)$.pdf (accessed 29 September 2018).

26. According to Szumkowski's estimates, his dictionary included 12,000 headwords in the Polish-English part and 18,000 in the English-Polish part.

27. Rejall selected 4,000 words, but Jesień introduced some changes to the list, adding a handful of words (e.g. die 'sztanca, kostka do gry, l.mn. dice (dajs)'), at the same time deleting others (e.g. dime).

28. Of course, this term should not be understood as equivalent with present-day "learner's dictionary" (see Hartmann and James 2001: 82-83), which includes features facilitating production in the TL.

29. A bilingual dictionary for inexperienced learners of English would call, whenever possible, for single-word equivalents rather than paraphrases. Taking this into account, surprise could be fairly effectively paired with three Polish equivalents: 'niespodzianka', 'zaskoczenie' and 'zdziwienie'.

30. The only reference to this edition, which is not available in any library, is found in Bilikiewicz-Blanc et al. (1991: 132).

31. Smulski was considered one of the "most brilliant and far-sighted" Polish Americans (Słownik Liliena ..., 1944: 3). Being aware of the importance of a modern Polish-English and EnglishPolish dictionary, he commissioned the task of compiling such a reference work to two of his talented collaborators, Henryk Setmajer and T.M. Wilde, paying them good salaries. The result of his bold initiative was, however, only the small volume under analysis here. 
32. With 600,000 headwords, Webster's Second was the largest monolingual English dictionary until the beginning of the twenty-first century and was regarded by users, even after the third edition appeared in 1961, as "the dictionary par excellence" (Landau 2001: 86). This may have resulted, to some extent, from the fact that the editor of Webster's Third took a less prescriptive approach to the compilation process, including substandard forms such as ain't, which sparked a wave of criticism throughout the United States (for which see Morton 1994).

33. Mizwa (1961: v) calls Lilien "a lawyer by training and lexicographer by avocation", but his legal qualifications are difficult to confirm.

34. In fact, Lilien gained wide experience in the press because, between 1887 and 1907, he was a co-owner of Kurier Lwowski, a popular weekly serving the city of Lvov (Mazurek 2006: 196).

35. He was, among other things, a member of the Linguistic Society of America (Proceedings of the Linguistic Society ..., 1953: 7), a corresponding member of the Polish Institute of Arts and Sciences in America (Pawlikowski et al. 1945: 428), a board member of Polish People's University (Pamiętnik dwudziestopięcioletniego jubileuszu ..., 1933: 19), and one of the sponsors of Poles in America (Tomczak 1933: 6). He also lectured on both linguistic and literary subjects (e.g. Lednicki 1976: 363-364).

36. Julius Chylinski was diocesan dean and pastor of St. Peter's parish in Stevens Point (Bolek 1943: 73). As issues of Stevens Point Journal (https://www.newspapers.com) indicate, he actively engaged in a range of enterprises, but, somewhat surprisingly, no information of St. Peter's Foundation is available today.

37. Mizwa was probing whether or not the Kosciuszko Foundation should invest money in Lilien's project. The support, it seems, would have been more generous if the dictionary had received a positive recommendation from Prof. George R. Noyes of the University of California (letter to Mizwa of 13 November 1945).

38. The letter of 17 February 1949 concerning Lilien's Dictionary was written by Czesław Miłosz, the 1980 Nobel Prize winner for literature, the then cultural attaché of the Embassy in Washington. This is no mere coincidence, as Franaszek (2017: 257-258) explains. He makes it clear that Miłosz recognized the full worth of Lilien's undertaking and went to great lengths to find some support for it: "I worked out a detailed plan for providing support to Ernest Lilien, the author and editor of a monumental Polish-English dictionary ... I can only express my disappointment and regret that although the project was supported by the Embassy in Poland, it has not met with approval (Embassy Report, August-September 1946)".

39. Lilien's correspondence provides a useful clue as to which edition of Webster's Second he had at his disposal: it was the 1944 edition with "A Pronouncing Biographical Dictionary" appended to it. Lilien was flabbergasted to see Copernicus' name in it spelled erroneously as Kopernicki (letter to Mizwa of 12 September 1946).

40. In his letter to Mizwa of 29 April 1945, Lilien states that he resorted to the 1896 edition of Funk and Wagnalls A Standard Dictionary ..., even though an updated version titled A New Standard Dictionary ... (1916) would have been a much better source. Yet, this dictionary was used less sparsely than Webster's Second.

41. OED3 explains that the word Hottentot is considered both archaic and offensive, so it is usually replaced by the word Khoekhoe. Bushman, denoting a member of an aboriginal people in Southern Africa, apparently comes from Dutch boschjesman applied by the Dutch colonists in South Africa to the Khoisan peoples living in the "bush". 


\section{References}

\section{Dictionaries}

Arct, M. 1916. Stownik ilustrowany języka polskiego. Vols. 1-3. Warsaw: Wydawnictwo M. Arcta.

Bulas K. and F.J. Whitfield. 1959. The Kościuszko Foundation Dictionary: English-Polish, Polish-English. Vol. 1: English-Polish. The Hague: Mouton.

Bulas K., F.J. Whitfield and L.L. Thomas. 1961. The Kościuszko Foundation Dictionary: English-Polish, Polish-English. Vol. 2: Polish-English. The Hague: Mouton.

Chodźko, A. 1870. Dokładny stownik polsko-angielski, czerpany z najlepszych źródeł krajowych $i$ obcych ... (Part 1). A Complete Dictionary, English and Polish (Part 2). Berlin: Neufeld \& Henius.

Chodźko, A. 1890. Chodzki Alexandra Doktadny stownik polsko-angielski i angielsko-polski, czerpany z najlepszych źródet krajowych i obcych ... (Part 1). Alex. Chodzko's A Complete Dictionary English and Polish and Polish and English. Compiled from the Dictionaries ... (Part 2). Chicago, IL: Drukiem i nakładem W. Dyniewicza.

Chodźko, A. c. 1950 [?]. Chodzki Alexandra Dokładny stownik polsko-angielski, czerpany z najlepszych źródeł krajowych i obcych: a mianowicie ze słowników polskich Lindego, Mrongoviusa i Ropelewskiego (Part 1). Alex Chodzko's A Complete Dictionary, English and Polish, Compiled from the Dictionaries of Johnson, Webster, Walker, Fleming and Tibbins, etc. (Part 2). Chicago: Polish American Publishing Co.

Flügel, J.G. 1830. A Complete Dictionary of the English and German and German and English Languages, Containing All the Words in General Use. Vols. 1-2. Leipsic: Printed for A.G. Liebeskind.

Funk and Wagnalls New Standard Dictionary of the English Language upon Original Plans ... Complete in One Volume. 1916. New York/London: Funk and Wagnalls.

Hartmann, R.R.K. and G. James. 2001. Dictionary of Lexicography. London/New York: Routledge.

Kierst, W. 1915-1916. Dokładny słownik angielsko-polski i polsko-angielski w dwóch częściach z wymowa wyrazów angielskich według najnowszych źródeł opracowany ... [Instalments 1-6]. Warsaw: Księgarnia Mazowiecka.

Kierst, W. 1984. A Dictionary English-Polish and Polish-English / Trzaski, Everta i Michalskiego stownik angielsko-polski i polsko-angielski. Część pierwsza angielsko-polska (Vol. 1). Second part: PolishEnglish (Vol. 2). New York: Saphrograph.

Kierst, W. and O. Callier. 1961. English-Polish and Polish-English Dictionary / Stownik jezzyka polskiego i angielskiego. Chicago: Drukiem "Dziennika Związkowego".

Lach-Szyrma, K. 1828. Stownik angielsko-polski ułożony przez K. L-S. dla użytku młodzieży Instytutu Politechnicznego. Warsaw: Drukarnia Gałęzowskiego i Komp.

Moszoro, K.W. 1946. Angielsko-polski słownik spawalniczy z omówieniem stosowanych lub przyjętych terminów oraz rysunkami. London: Wojskowy Instytut Techniczny.

Neilson, W.A., T.A. Knott and P.W. Carhart (Eds.). 1934. Webster's New International Dictionary of the English language. 2nd edition. Springfield, MA: Merriam-Webster.

OED3 = Simpson, J., M. Proffitt et al. (Eds.). 2000-. The Oxford English Dictionary. 3rd edition. Oxford: Oxford University Press. http://www.oed.com/.

Ogilvie, J. 1859-1860. The Imperial Dictionary of the English Language: A Complete Encyclopedic Lexicon, Literary, Scientific, and Technological. Vols. 1-3. London: Blackie and Son. 
Perry, W. 1788. The Royal Standard English Dictionary, in Which the Words Are Not Only Rationally Divided into Syllables, Accurately Accented, Their Part of Speech Properly Distinguished, and Their Various Significations Arranged in One Line, but Likewise ... London: Printed for, and sold by J. Murray .... and J. Bell and J. Dickson.

Stownik warszawski [Warsaw Dictionary] = Karłowicz, J., A.A. Kryński and W. Niedźwiedzki (Eds.). 1900-1927. Stownik języka polskiego. Vols. 1-8. Warsaw: Nakładem prenumeratorów i Kasy im. Mianowskiego [and others].

Stownik betoniarza i zbrojarza polsko-angielski i angielsko-polski. 1947. London: Inspektorat Szkolenia P.K.P.R.

Stownik ślusarza angielsko-polski. Cz. 1: Narzędzia i materiaty. Cz. 2: Czynności ślusarskie. 1946. [Great Britain]: Biuro Badań Technicznych Saperów.

Stanisławski, J. 1933. An English-Polish and Polish-English Pocket-Dictionary / Stowniczek angielskopolski i polsko-angielski. Třebič, Moravia: J. Lorenz.

Stanisławski, J. 1993. McKay's English-Polish and Polish-English Pocket-Dictionary. [Montreal]: Tormont.

Webster, N., W.G. Webster and W.A. Wheeler. 1871. A Primary School Dictionary of the English Language, Explanatory, Pronouncing and Synonymous. With an Appendix Containing Various Useful Tables. New York/Chicago: Ivison, Blakeman, Taylor \& Co.

Webster's Collegiate Dictionary (1919). 3rd edition. Springfield, MA: G. \& C. Merriam Co.

Webster's Second = Neilson, W.A., T.A. Knott and P.W. Carhart (Eds.). 1934. Webster's New International Dictionary of the English Language. 2nd edition. Springfield, MA: Merriam-Webster.

Whitney, W.D. and B.E. Smith (Eds.). 1895. The Century Dictionary: An Encyclopedic Dictionary of the English Language. Vols. 10. New York: The Century.

\section{Other references}

Adamska-Sałaciak, A. 2014. Bilingual Lexicography: Translation Dictionaries. Hanks, P. and G.-M. de Schryver (Eds.). 2014. International Handbook of Modern Lexis and Lexicography: 1-11. Berlin: Springer.

Antonowicz, J. 1788. Grammatyka dla Polaków chcacych się uczyć angielskiego języka krótko zebrana przez ... Bazyliana prowincyi litewskiéy za pozwoleniem zwierzchności pierwszy raz pod prasse oddana. Warsaw: W Drukarni Nadworney J.K. Mci i P.K. Edu.

Barry, A. 2008. Reading the Past: Historical Antecedents to Contemporary Reading Methods and Materials. Reading Horizons 49(1): 31-52.

Bilikiewicz-Blanc, D. et al. 1991. Polonika zagraniczne: bibliografia za okres od września 1939 do 1955 roku. Vol. 3: R-Ż. Warsaw: Biblioteka Narodowa.

Bolek, F. (Ed.). 1943. Who's Who in Polish America. A Bibliographical Directory of Polish-American Leaders and Distinguished Poles Resident in the Americas. 3rd edition. New York: Harbinger House.

Boyer, A. 1729. The Compleat French-Master for Ladies and Gentlemen. Containing I. A New Methodical French Grammar. II. A Well Digested and Copious Vocabulary. III. Familiar Phrases and Dialogues, on All Manner of Subjects ... London: Printed for Samuel Ballard et al.

Burroughs, E.R. 1922. Tarzan wśród małp. Translated from English by Władysław Kierst. Warsaw: Trzaska, Evert i Michalski. 
Chłapowski, F. 1884. Truskawiec: we wschodniej Galicyi. Kłosy: Czasopismo Ilustrowane Tygodniowe of 30 August-11 September 1884, 39(1002): 171-173. http://www.wbc.poznan.pl/dlibra/ publication?id=170061\&tab=3 (accessed 29 September 2018).

Coleman, J. 2008. A History of Cant and Slang Dictionaries. Volume III: 1859-1936. Oxford: Oxford University Press.

Collison, R.L. 1955. Dictionaries of Foreign Languages: A Bibliographical Guide to the General and Technical Dictionaries of the Chief Foreign Languages, with Historical and Explanatory Notes and References. London: Hafner Publishing.

Czartoryski-Sziler, P. (n.d.) Wielcy zapomniani: Władysław Biełza - wielki piewca polskości. Nasz Dziennik. http://www.lwow.home.pl/naszdziennik/belza2.html (accessed 29 September 2018).

Emans, R. 1968. History of Phonics. Elementary English 45(5): 602-608.

Erdmans, M.P. 2013. Acculturation and Persistence of the Polish American Community in Connecticut, 1870-2010. Mazurkiewicz, A. (Ed.). 2013. East Central Europe in Exile. Volume 1: Transatlantic Migrations: 217-234. Newcastle-upon-Tyne: Cambridge Scholars Publishing.

Franaszek, A. 2017. A Biography: Miłosz. Edited and translated by Aleksandra and Michael Parker. Cambridge, MA/London: Belknap Press of Harvard University Press.

Graff, E.V. de. 1881. Practical Phonics. A Comprehensive Study of Pronunciation, Forming a Complete Guide to the Study of the Elementary Sounds of the English Language, and Containing Three Thousand Words of Difficult Pronunciation, with Diacritical Marks According to Webster's Dictionary. Syracuse, NY: C.W. Bardeen Publisher.

Grzegorczyk, P. 1967. Index lexicorum Poloniae. Warsaw: Państwowe Wydawnictwo Naukowe.

Hargraves, O. 2011. Culture Shock! Chicago. A Survival Guide to Customs and Etiquette. Tarrytown, NY: Marshall Cavendish Editions.

Hartmann, Reinhard R.K. 2007. Interlingual Lexicography. Selected Essays on Translation Equivalence, Contrastive Linguistics and the Bilingual Dictionary. Tübingen: Max Niemeyer.

Hausmann, F.J., O. Reichmann, H.E. Wiegand and L. Zgusta (Eds.). 1991. Wörterbücher. Ein internationales Handbuch zur Lexikographie / Dictionaries. An International Encyclopedia of Lexicography / Dictionnaires. Encyclopédie internationale de lexicographie. Vol. 3. Berlin/New York: Walter de Gruyter.

Jaroszyńska-Kirchmann, A. 2015. The Polish Hearst: Ameryka-Echo and the Public Role of the Immigrant Press. Urbana: University of Illinois Press.

Kantowicz, E.R. 1975. Polish-American Politics in Chicago, 1880-1940. Chicago: University of Chicago Press.

Kąsinowski, B. 1913. Władysław Bełza ${ }^{*} 1847+1913$. Literatura i Sztuka. Dodatek do Dziennika Poznańskiego 5(6): 81-83.

Landau, S. 2001. Dictionaries. The Art and Craft of Lexicography. Cambridge: Cambridge University Press.

Lednicki, W. 1976. Adam Mickiewicz in World Literature. A Symposium. Westport, CT: Greenwood Press.

Lewandowski, I. 1992. Rykaczewski Erazm Edward (1803-1873). Polski Słownik Biograficzny 33(3): 472-474.

Lewański, R.C. 1959. A Bibliography of Slavic Dictionaries: With a Supplement of Lusatian and Polabian Dictionaries. Vol. 1: Polish. New York: New York Public Library. 
Lilien, E. 1944. Preface. Lilien's Dictionary. Part I: English-Polish Lilien's Dictionary / Ernesta Liliena stownik. Cz. 1: Angielsko-polski. Buffalo: Drukiem Dziennika dla Wszystkich.

Lokański, H. 1920. Sześć lat wojny Polskiej a Polacy w Ameryce. Chicago: [no publ.].

Łukasik, M. 2017. Polish Specialised Lexicography during WWII. Lipczuk, R., M. Lisiecka-Czop, K. H. Ramers (Eds.). 2017. Sprache und Wörterbucher in Theorie und Praxis. Lexikografische und textlinguistische Fragestellungen: 105-124. Hamburg: Dr Kovač.

Maciejewski, J. and Z. Szweykowski (Eds.). 1982. Bibliografia literatury polskiej Nowy Korbut. Literatura pozytywizmu i Młodej Polski. Vol. 16. Warsaw: Państwowy Instytut Wydawniczy.

Majewski, K. 2003. Traitors and True Poles. Narrating a Polish-American Identity 1880-1939. Athens, OH: Ohio University Press.

Maryański, M. 1882. Kopalnie Truskawieckie. Gazeta Lwowska of 22 July 1882, 72(166): 3-4. https://jbc.bj.uj.edu.pl/dlibra/publication/54184/edition/48401/content?ref=desc (accessed 29 September 2018).

Mazurek, J. 2006. Kraj a emigracja. Ruch ludowy wobec wychodźstwa chtopskiego do krajów Ameryki Łacińskiej. Warsaw: Instytut Studiów Iberyjskich i Iberoamerykańskich.

Micklethwait, D. 2005. Noah Webster and the American Dictionary. Jefferson, NC/London: McFarland \& Company.

Mizwa, S.P. 1961. Preface. Bulas, Kazimierz and Francis J. Whitfield (Eds.). 1961. The Kościuszko Foundation Dictionary English-Polish Polish-English. Volume 1: English-Polish. The Hague: Mouton \& Co.

Morton, H.C. 1994. The Story of Webster's Third: Phillip Gove's Controversial Dictionary and Its Critics. New York/Cambridge: Cambridge University Press.

[Obituary of] Ernest Lilien. 1952. The Milwaukee Journal of 16 June 1952: 23. https://news.google. $\mathrm{com} /$ newspapers?nid=1499\&dat=19520616\&id=GQ8iAAAAIBAJ\&sjid=XH4EAAAAIBAJ\&p $\mathrm{g}=6843,128624 \& \mathrm{hl}=\mathrm{en}$ (accessed 29 September 2018).

Osselton, N.E. 2007. Alphabet Fatigue and Compiling Consistency in Early English Dictionaries. Considine, J. and G. Iamartino (Eds.). 2007. Words and Dictionaries from the British Isles in Historical Perspective: 81-91. Newcastle-upon-Tyne: Cambridge Scholars Publishing.

Pamiętnik dwudziestopięcioletniego jubileuszu Polskiego Uniwersytetu Ludowego w Stanach Zjednoczonych / 25th Jubilee Memorial Record of the Polish People's University in the U.S. 1933. Chicago, ILL: [no pub.].

Paryski, A.A. 19--. Katechizm dla agenta oświatowego wydawnictwa Ameryki-Echa. Toledo, OH: Wydawnictwo Ameryki-Echa.

Paszkowski, L. 1987. Poles in Australia and Oceania 1790-1940. Sydney: Australian National University Press.

Paszkowski, L. 2008. Polacy w Australii i Oceanii 1790-1940. Toruń/Melbourne: Towarzystwo Przyjaciół Archiwum Emigracji.

Pawlikowski, J. et al. 1945. General Development of the Institute. Bulletin of the Polish Institute of Arts and Sciences in America 3(3/4): 422-453.

Podhajecka, M. 2016a. A History of Polish-English / English-Polish Bilingual Lexicography (1788-1947). Opole: Wydawnictwo Uniwersytetu Opolskiego.

Podhajecka, M. 2016b. Szkic z dziejów leksykografii dwujęzycznej: Paweł Sobolewski i jego słownik angielsko-polski ... (1840). Prace Filologiczne 68: 323-344. 
Proceedings of the Linguistic Society of America at the Twenty-Seventh Annual Meeting Cambridge 28-29 December 1952. Bulletin 26, 1953. Language: Journal of the Linguistic Society of America 29(2): 6-20.

Pula, J. et al. (Eds.). 2011. The Polish American Encyclopedia. Jefferson, NC/London: McFarland \& Company.

Scherer, P. 1946. Review of: Lilien's Dictionary. Part I: English-Polish, fascicles 1-6 by Ernest Lilien. Language 22(3): 265-266.

Stinchfield-Hawk, S. 1928. The Psychology of Speech. Boston: Expression.

Tomczak, A.C. (Ed.). 1933. Poles in America. Their Contribution to a Century of Progress. A Commemorative Souvenir Book Compiled and Published on the Occasion of the Polish Week of Hospitality, July 17 to 23. Chicago, IL: Polish Day Association.

Wojan, K. 2013. Jezzyk angielski w polskiej leksykografii. Stowniki przekładowe lingwistyczne i encyklopedyczne wydane w latach 1782-2012. Gdańsk: Wydawnictwo Uniwersytetu Gdańskiego.

\section{Archival materials}

Chojnacki, W. (n.d.) Antoni A. Paryski (1864-1935) — wydawca polski w Ameryce. The Archives of the Polish Museum of America in Chicago, manuscript.

Lilien, E. to S. Mizwa. Letter of 8 June 1944. The Archives of the Kosciuszko Foundation, XVII.10. Ernest Lilien.

Lilien, E. to S. Mizwa. Letter of 29 April 1945. The Archives of the Kosciuszko Foundation, XVII.10. Ernest Lilien.

Lilien, E. to S. Mizwa. Letter of 12 September 1946. The Archives of the Kosciuszko Foundation, XVII.10. Ernest Lilien.

Miłosz, C. to Towarzystwo Uniwersytetów Robotnicznych [Society of People's Universities]. Letter of 17 February 1949. The Archives of Modern Records in Warsaw, No. 566/66/49.

Noyes, G.R. to S. Mizwa. Letter of 13 November 1945. The Archives of the Kosciuszko Foundation, XVII.10. Ernest Lilien.

Słownik Liliena - cenne dzieło naukowe na wychodźstwie. 1944. Dziennik dla Wszystkich of 30 January 1944: 3. The Archives of the Kosciuszko Foundation, XVII.10. Ernest Lilien.

Sobolewski, P. [1840]. English and Polish Dictionary, Containing All Words and Phrases of General Use (With the Pronunciation of Every English Word According to Walker) to Which is Also Added a Complete Table of Irregular Verbs of the English Language / Stownik Angielsko-Polski, zawierajacy wsobie wszystkie słowa i frazesa w powszechnem użwaniu ... (B-E). The Polish Library in Paris, manuscript. 